\title{
Electrochemical Processes for the Treatment of Hazardous Wastes Exemplified by Electroplating Sludge Leaching Solutions
}

\author{
Nan Wu ${ }^{1,2,3, * \mathbb{D}}$, Xue Zhang ${ }^{4}$, Xuemin Zhang ${ }^{1,2,3}$, Yanjuan Li $^{5}$, Xiaosan Song ${ }^{1,2,3}$ and Sanfan Wang ${ }^{1,2,3}$ \\ 1 Key Laboratory of Yellow River Water Environment in Gansu Province, Lanzhou Jiaotong University, \\ Lanzhou 730070, China; zhangxuemin@mail.lzjtu.cn (X.Z.); songxs@mail.lzjtu.cn (X.S.); \\ sfwang1612@163.com (S.W.) \\ 2 School of Environment and Municipal Engineering, Lanzhou Jiaotong University, Lanzhou 730070, China \\ 3 Engineering Research Center for Cold and Arid Regions Water Resource Comprehensive Utilization, \\ Ministry of Education, Lanzhou 730070, China \\ 4 Department of Environmental Science and Engineering of ZHIXING, College of Northwest Normal University, \\ Lanzhou 730070, China; zhangxue0431@163.com \\ 5 School of Civil Engineering, Lanzhou University of Technology, Lanzhou 730050, China; mmlyj2003@163.com \\ * Correspondence: wunan0516@163.com; Tel.: +86-931-4956083
}

Citation: Wu, N.; Zhang, X.; Zhang, X.; Li, Y.; Song, X.; Wang, S.

Electrochemical Processes for the Treatment of Hazardous Wastes Exemplified by Electroplating Sludge Leaching Solutions. Water 2021, 13, 1576. https://doi.org/10.3390/ w13111576

Academic Editor: Chin-Pao Huang

Received: 7 April 2021

Accepted: 31 May 2021

Published: 2 June 2021

Publisher's Note: MDPI stays neutral with regard to jurisdictional claims in published maps and institutional affiliations.

Copyright: ( $\odot 2021$ by the authors Licensee MDPI, Basel, Switzerland. This article is an open access article distributed under the terms and conditions of the Creative Commons Attribution (CC BY) license (https:// creativecommons.org/licenses/by/ $4.0 /)$.

\begin{abstract}
The solidified landfill disposal of hazardous solid waste such as electroplating sludge in arid/semi-arid areas has potential risks and hazards. In this study, the electrochemical method was used to destroy the structures of metal complexes in electroplating sludge and release metal ions so that the organics were removed by direct mineralization in the anode while the metal was recovered in the cathode. $\mathrm{A} \mathrm{SnO}_{2} / \mathrm{Ti}$ electrode was used as the anode during the electrolysis process. The effect of different current densities $\left(10,20,30,40,50,60 \mathrm{~A} / \mathrm{m}^{2}\right)$, different $\mathrm{pH}$ values $(2,3,4,5,6)$, and the presence of chloride $(0.1$ or $0.2 \mathrm{M} \mathrm{NaCl})$ and sulfate $\left(0.1\right.$ or $\left.0.2 \mathrm{M} \mathrm{Na}_{2} \mathrm{SO}_{4}\right)$ on treatment were investigated. Under the optimal treatment conditions (current density $=50 \mathrm{~A} / \mathrm{m}^{2}, \mathrm{pH}=3$ ), the removal rates of $\mathrm{COD}_{\mathrm{Cr}}, \mathrm{TOC}$, and $\mathrm{Ni}^{2+}$ reached $88.01 \%, 85.38 \%$, and $97.57 \%$, respectively, with a metal recovery of $97.01 \%$. Further studies showed that active chlorine and active persulfate generated in the presence of chloride and sulfate had less effect on the removal of organics, while hydroxyl radicals played a major role. The dilution of the leachate would be detrimental to electrochemical treatment. The by-products of organic chlorination were produced in low amounts, mainly $\mathrm{CHCl}_{3}$. This method can be used to treat electroplating sludge in various areas to recover valuable metals while removing organic pollutants, complying with the concept of sustainable development. This method provides a new solution for the treatment of metal-containing hazardous solid waste such as electroplating sludge from the perspective of practical application.
\end{abstract}

Keywords: arid/semi-arid areas; hazardous solid wastes; electroplating sludge; electrochemistry; environmentally friendly disposal

\section{Introduction}

Electroplating sludge is listed in the National Hazardous Waste List (2021) in the HW17 and HW21 waste categories due to the presence of heavy metals such as Ni, Pb, $\mathrm{Cu}$, and other toxic substances that are classified as hazardous solid wastes. Heavy metals in electroplating sludge are often not in the form of single metal ions but in the form of metal complexes, metal chelates, and other organic heavy metals, which are biomethylated under natural conditions, are lipid soluble, and have strong biological toxicity. Disposal must be carried out, and common methods include solidification landfills, thermochemical treatment, and materialization techniques [1-5]. Solidified landfill is an important final disposal method for solid wastes (including hazardous wastes). If the site selection or engineering measures are not appropriate in the process of landfill disposal, the impermeable layer will be damaged and leaked with the resultant extension of operation 
time, leading to the contamination of soil and groundwater in the area due to the infiltration of contaminants [6-9]. The infiltrating pollutants include a variety of contaminants such as heavy metals, aromatic hydrocarbons, and phenols, which seriously damage the fertility of soil and endanger human health through the food chain. Treating hazardous solid wastes such as electroplating sludge by solidified landfill is potentially harmful, and a method that can address such metal-containing hazardous solid wastes from the source is urgently needed.

It is generally believed that solid wastes are more suitable for landfill disposal in arid/semi-arid areas than in wet areas because arid/semi-arid areas have desert-like topography, and it is very easy to find suitable sites for landfill [10-13]. Nevertheless, since the soil moisture in arid/semi-arid areas is less than that in wet areas, the dilution capacity of soil is weak, the infiltration pollutants are more concentrated in the soil, the pollution level increases due to a high concentration of pollutants in the local area, and the pollution multiplier is much higher than that in wet areas. This kind of concentrated pollution due to the lack of natural dilution conditions causes the pollutant concentration to increase with the prolonged operation time. This can lead to persistent pollution, and when encountered with heavy rainfall or floods, the concentrated release of pollutants can easily occur, causing a wide range of soil, groundwater, and surface water pollution, resulting in much greater damage to the environment than in wet areas. In dry climates, rising groundwater levels may produce more leachate, especially persistent contaminants including pesticides and heavy metals that are more hazardous [14-18]. Hence, landfills alone are not sufficient in arid/semi-arid areas, especially for the environmentally sound disposal of hazardous solid wastes. Arid/semi-arid areas generally have a low resource carrying capacity, and once contamination occurs, it will cause serious, even irreversible, ecological damage. Additionally, due to the unique climatic characteristics of these areas, surface water resources are less available, and the demand for groundwater is more intense than in the wetter areas, which requires a higher degree of groundwater protection [19]. Therefore, hazardous wastes should be disposed of with more attention given to the selection of process management and disposal technologies in arid/semi-arid areas. Currently, the quantity of hazardous wastes produced is increasing year by year, but there are few studies on how to treat hazardous wastes rationally, effectively, and harmlessly under arid/semi-arid conditions. The existing studies have mainly focused on how to treat contaminated soil and groundwater, and few studies have explored how to reduce or solve the issue of hazardous wastes at the source $[4,5]$.

Gansu Province in northwestern China was studied in this research because the central and northern part of the province are typical semi-arid/arid regions, and rainfall occurs mostly in the summer, which can easily cause heavy rain and floods in mountainous and central arid areas. The region is rich in mineral resources, with 35 types of metal minerals identified. There are large enterprises such as Jinchuan Group and Jiugang Group, among which Jinchuan ranks second in the world in Co production and fourth in Ni production, making it an important non-ferrous metallurgical production base in China [20]. The climatic characteristics and industrial features of this area indicate an urgent need for a nonhazardous technology for the treatment of metallic solid waste. Heavy metals in wastewater are usually treated by electrochemical cathode reduction. Additionally, electrochemical processes can be used to partially degrade or completely mineralize organics using anode oxidation. However, these two types of studies are often carried out separately. At present, it is rare to see studies on the mineralization of organics and the reduction of heavy metals in one system [21,22]. In this study, in light of the regional industry, climatic characteristics, and the advantages of electrochemical techniques, solid wastes such as electroplating sludge were selected as the research object, given their toxicity, difficult treatment, and high recovery value. Electrochemical technology was used to directly oxidize organics from which metals could be recovered, and a technically feasible, economically reasonable disposal scheme was designed to solve the problem of the harmless disposal of metalcontaining solid wastes and recycling heavy metals. The results can provide theoretical 
and technical support for the practical application of such pollutant treatment projects and a solution for the harmless disposal of electroplating sludge.

\section{Experiment and Theories}

\subsection{Electrochemical Oxidation and Reduction}

During the electrochemical reaction, the anode undergoes an oxidation reaction, and under the catalytic effect of a special electrode, various active substances are released including active oxygen, active chlorine, and active peroxydisulfate, depending on the electrode material or the nature of the solution. They have strong oxidizing properties and are capable of treating difficult-to-degrade organics. In the case of $\cdot \mathrm{OH}$, for example, the first step of the reaction is to release water molecules and form adsorbed hydroxyl radicals:

$$
\mathrm{MO}_{\mathrm{x}}+\mathrm{H}_{2} \mathrm{O} \rightarrow \mathrm{MO}_{\mathrm{x}}(\cdot \mathrm{OH})+\mathrm{H}^{+}+\mathrm{e}^{-}
$$

The following reactions were divided into two categories according to the nature of electrode materials: one was the active anode (e.g., $\mathrm{IrO}_{2}, \mathrm{RuO}_{2}$ ) [23-25], and the other was the non-active anode (e.g., $\mathrm{SnO}_{2}, \mathrm{PbO}_{2}$ ) [26-28].

(a) On the active anode, the chemically absorbed hydroxyl radicals might interact with the anode to form higher valence oxides, which then undergo conversion or selective oxidation of the organics:

$$
\begin{gathered}
\mathrm{MO}_{\mathrm{x}}(\cdot \mathrm{OH}) \rightarrow \mathrm{MO}_{\mathrm{x}+1}+\mathrm{H}^{+}+\mathrm{e}^{-} \\
\mathrm{MO}_{\mathrm{x}+1}+\mathrm{R} \rightarrow \mathrm{MO}_{\mathrm{x}}+\mathrm{RO}
\end{gathered}
$$

(b) On the non-active anode, higher valence oxides cannot be generated, and the active oxygen radicals of physical adsorption can carry out non-selective oxidation of organics, which might lead to complete combustion of organics into $\mathrm{CO}_{2}[29,30]$;

$$
\mathrm{MO}_{\mathrm{x}}(\cdot \mathrm{OH})+\mathrm{R} \rightarrow \mathrm{MO}_{\mathrm{x}}+\mathrm{CO}_{2}+\mathrm{H}_{2} \mathrm{O}+\mathrm{H}^{+}+\mathrm{e}^{-}
$$

For both anodes, the side reaction of oxygen evolution occurs in the oxidation reaction, affecting the oxidation effect [30]. In the cathode, the reduction reaction occurs, and lowvalent metals with low oxidation potential (e.g., $\mathrm{Ni}, \mathrm{Co}, \mathrm{Zn}, \mathrm{Cu}$ ) are precipitated directly, leading to the following reaction:

$$
\mathrm{M}^{\mathrm{n}+}+\mathrm{ne} \rightarrow \mathrm{M} \downarrow
$$

\subsection{Non-Active Anode}

The active anode can induce the electrochemical conversion of organics to more biodegradable molecules such as short-chain carboxylic acids, which cannot achieve complete mineralization or organic combustion to $\mathrm{CO}_{2}$, while the non-active anode reaction generates $\cdot \mathrm{OH}$ radicals, which are physically adsorbed on the anode surface, which has high instability, strong reactivity, and high oxidation power, facilitating the complete electrochemical oxidation of organic pollutants to $\mathrm{CO}_{2}$. The non-active anode inhibits the production of active chlorine and effectively reduces the production of undesirable organic chlorinated by-products (e.g., halo-acetic acid, halo-methane) and harmful ionic substances (e.g., chlorate, perchlorate) from the oxidation of active chlorine organics (e.g., methane) and harmful ionic substances (e.g., chlorate, perchlorate) [29-31].

The presence of organics in electroplating sludge is caused by the addition of additives, brighteners, and coating agents in the electroplating process. These polymers and their monomers contain primary amines, quaternary amines, and amide groups, which have been shown to be precursors for the formation of organochlorinated by-products. At the same time, electroplating sludge has chloride ions, and active chlorine formed during the oxidation of the electrochemical anode might generate organochloride by-products 
with these precursors. It is therefore necessary to monitor the content of trihalomethanes (THMs) after electrochemical treatment [32-34].

The $\mathrm{SnO}_{2} /$ Ti electrode is a typical non-active anode, and $\cdot \mathrm{OH}$ precipitated on its surface has a strong oxidizing ability, which is non-selective for the oxidation of organics and leads to complete combustion to $\mathrm{CO}_{2}$. Less chlorine is generated in chlorinated media, and the potential for harmful chlorinated organic by-products is smaller, making it the ideal anode for industrial wastewater treatment $[27,28,30]$.

\subsection{Experimental Hypothesis}

Electrochemical treatment begins by dissolving the electroplating sludge into a solution, using nitric acid to avoid the use of hydrochloric acid to form a chlorine-containing system, and then the electrochemical process is used to separate the organics and heavy metals in the electroplating sludge by oxidation and reduction, respectively. The organics and heavy metals in the electroplating sludge are separated and disposed of harmlessly by electrochemistry. After the electroplating sludge is dissolved, the metal complexes are destroyed by the action of $\cdot \mathrm{OH}$ generated by the anode to release heavy metal ions. The released heavy metal ions are reduced to metal in the cathode. In addition to $\mathrm{Ni}, \mathrm{Co}, \mathrm{Pb}$, $\mathrm{Zn}$, and $\mathrm{Cu}$, which are attached to the cathode, some ions $\left(\mathrm{Cr}_{2} \mathrm{O}_{7}{ }^{2-}, \mathrm{Cd}^{2+}\right)$ are precipitated in the form of powder at the bottom of the cathode by controlling the current and $\mathrm{pH}$ value, and the metals are obtained by filtration. As a result of continuous energization, the toxic substances in electroplating sludge can be completely disposed of, and various types of electroplating sludge can be disposed of by changing the electrode materials and operating parameters, thus changing the existing electroplating sludge solidification and landfill treatment method, transforming the electroplating sludge morphology, eliminating potential hazards, and recovering useful metals. This method overcomes the difficulties of the cumbersome treatment process and low separation efficiency demonstrated by some studies in which the morphology of the electroplating sludge was destroyed first, then the separation of organics and heavy metals was carried out before the separate treatment of heavy metals and organics.

\section{Materials and Methods}

\subsection{Dissolution of Solid Waste Samples}

The electroplating sludge of an electroplating enterprise in Gansu Province was used as the raw material. The $\mathrm{pH}$ value of the untreated electroplating sludge was 7.09, water content was $82.65 \%$, and ash content was $75.44 \%$. According to the Classification of Electroplating Sludge Treatment and Disposal (GB/T38066-2019), the sludge can be classified as nickel sludge in electroplating sludge. A small amount was slurried and pretreated with $1 \mathrm{M}$ nitric acid for $0.5 \mathrm{~h}$. After nitric acid leaching, the metal components were dissolved into the solution, and some impurities were removed [35]. In this study, the electroplating sludge leaching solution was studied, and $\mathrm{Ni}$ was present in the form of ethylene diamine tetraacetic acid (EDTA) complexes and ions. Table 1 shows the main characteristics of the leaching solution.

Table 1. Leaching solution wastewater characteristics.

\begin{tabular}{ccc}
\hline & Unit & Value \\
\hline Chemical oxygen demand (COD) & $\mathrm{mg} / \mathrm{L}$ & 28,000 \\
EDTA & $\mathrm{mg} / \mathrm{L}$ & 35,000 \\
Total organic carbon (TOC) & $\mathrm{mg} / \mathrm{L}$ & 9500 \\
$\mathrm{Ni}^{2+}$ & $\mathrm{mg} / \mathrm{L}$ & 47,300 \\
$\mathrm{Al}^{3+}$ & $\mathrm{mg} / \mathrm{L}$ & 4120 \\
$\mathrm{Ca}^{2+}$ & $\mathrm{mg} / \mathrm{L}$ & 2380 \\
$\mathrm{Cu}^{2+}$ & $\mathrm{mg} / \mathrm{L}$ & 48 \\
$\mathrm{PO}_{4}{ }^{-}$ & $\mathrm{mg} / \mathrm{L}$ & 17,300 \\
$\mathrm{SO}_{4}^{2-}$ & $\mathrm{mg} / \mathrm{L}$ & 761 \\
$\mathrm{Cl}^{-}$ & $\mathrm{mg} / \mathrm{L}$ & 318 \\
$\mathrm{pH}^{-}$ & & 3.04 \\
\hline
\end{tabular}




\subsection{Experimental Setup}

Experiments were performed in a single-chamber electrochemical reactor with a size of $6 \times 6 \times 6 \mathrm{~cm}^{3}$. The anode was a $\mathrm{SnO}_{2} /$ Ti electrode, the cathode was an Ni electrode, and the size of the electrode was $4 \times 4 \times 0.1 \mathrm{~cm}^{3}$. Electrode spacing was $3 \mathrm{~cm}$.

In the experiments, the current density was $10,20,30,40,50,60 \mathrm{~A} / \mathrm{m}^{2}$; the initial $\mathrm{pH}$ value was $2,3,4,5,6$; and the $\mathrm{NaCl}$ or $\mathrm{Na}_{2} \mathrm{SO}_{4}$ concentration was 0.1 or $0.2 \mathrm{M}$, respectively. The volume ratios of leachate to deionized water (DI water) were 100:0, 75:25, 50:50, and 25:75. The initial $\mathrm{pH}$ value was adjusted using nitric acid or sodium hydroxide. Samples were taken from the electrolytic cell at 0 (initial), 5, 10, 20, 30, 45, 60, 90, 120, and $150 \mathrm{~min}$.

\subsection{Analysis}

$\mathrm{COD}_{\mathrm{Cr}}$ was measured using a $\mathrm{COD}_{\mathrm{Cr}}$ tester (version 5B-3A, Lianke, Beijing, China), TOC was measured with a TOC/TN analyzer (MULTI N/C2100, Analytik Jena, Jena, Germany), and a $\mathrm{pH}$ meter (BPH-7200, Bell, Dalian, China) was used for $\mathrm{pH}$ measurement. $\mathrm{Ni}^{2+}$ was measured using a flame atomic absorption spectrophotometer with a wavelength of $324.7 \mathrm{~nm}$ (AA-7000, Shimadzu, Kyoto, Japan). Organic chlorinated by-products including $\mathrm{CHCl}_{3}$, $\mathrm{CHCl}_{2} \mathrm{Br}, \mathrm{CHClBr}_{2}$, and $\mathrm{CHBr}_{3}$ were measured by using gas chromatography (GC-MS 7000C, Agilent, Palo Alto, CA, USA) with a capillary column of $30 \mathrm{~m} \times 320 \mu \mathrm{m} \times 0.25 \mu \mathrm{m}(\mathrm{HP}-5$, Agilent, Palo Alto, CA, USA).

The effect of $C O D_{C r}, T O C$, and heavy metal was characterized by residual rate (i.e., $C_{t} / C_{0}$, where $C_{0}$ and $C_{t}$ are the initial concentrations and concentrations at $t$-time, respectively, of $\mathrm{COD}_{\mathrm{Cr}}, \mathrm{TOC}$, and $\mathrm{Ni}^{2+}$ ).

The instantaneous current efficiency (ICE) obtained from $\mathrm{COD}_{\mathrm{Cr}}$ measurements, was calculated as follows [30]:

$$
\mathrm{ICE}=\mathrm{FV} \frac{\mathrm{COD}_{0}-\mathrm{COD}_{\mathrm{t}}}{8 \mathrm{I} \Delta \mathrm{t}} \times 100 \%
$$

where $\mathrm{F}$ is the Faraday constant $(96,487 \mathrm{C} / \mathrm{mol}) ; \mathrm{V}$ is the volume $(\mathrm{L}) ; \mathrm{COD}_{0}$ and $\mathrm{COD}_{\mathrm{t}}$ represent the COD concentration $(\mathrm{mg} / \mathrm{L})$ at the beginning of the experiment and after $\mathrm{t}$ time of electrolysis $(\mathrm{mg} / \mathrm{L}) ; 8$ is the equivalent weight of oxygen $(\mathrm{g} / \mathrm{eq})$; I is the current $(\mathrm{A})$; and $\Delta \mathrm{t}$ is the electrolysis time (s).

\section{Results and Discussion}

\subsection{Effects of Current Density}

Figure 1 shows the removal effect of $\mathrm{COD}_{\mathrm{Cr}}, \mathrm{TOC}$, and $\mathrm{Ni}^{2+}$ at different current densities; with the increase in current density, the residual rate of organics and heavy metal in wastewater decreased significantly. As shown in Figure 1a, as the current density increased from 10 to $50 \mathrm{~A} / \mathrm{m}^{2}$, the removal efficiency of $\mathrm{COD}_{\mathrm{Cr}}$ increased from $50 \%$ to $85 \%$ after $120 \mathrm{~min}$ of electrolysis. The oxidation effect was not only related to the oxidizing ability of the oxidant itself, but also to the concentration of the oxidant. Increasing the current density could accelerate the electrochemical reaction of the anode, promote the production rate of $\cdot \mathrm{OH}$ radicals, and increase the concentration of the oxidant. Increasing the current density not only accelerated the production of the oxidant, but also promoted the electron transfer between organic pollutants and the electrode, which improved the oxidation effect. According to reports, EDTA was first degraded to $\mathrm{R}_{3} \mathrm{~N}$ by the action of strong oxidizing agents and then underwent the mineralization process of $\mathrm{R}_{3} \mathrm{~N} \rightarrow \mathrm{R}_{2} \mathrm{NH} \rightarrow \mathrm{H}_{2} \mathrm{NR} \rightarrow \mathrm{NH}_{4}{ }^{+}$ $+\mathrm{HOOC}-\mathrm{COOH} \rightarrow \mathrm{CO}_{2}+\mathrm{H}_{2} \mathrm{O}+\mathrm{NH}_{3}$, and the main oxidation intermediates were amino acids $[36,37]$. $\mathrm{OH}$ had a strong electron affinity and could easily attack high electron cloud density sites. Hydroxyl radicals extracted hydrogen from the alkyl groups. The structure was destroyed, converted to intermediates, and then mineralized [38,39]. Compared with $50 \mathrm{~A} / \mathrm{m}^{2}$, the $\mathrm{COD}_{\mathrm{Cr}}$ removal effect at $60 \mathrm{~A} / \mathrm{m}^{2}$ was not significantly increased. This might be attributed to the fact that at higher current density, the anode underwent more side reactions of oxygen evolution with weak oxidation capacity, which competed with the main reaction, while the electrode surface generated various bubbles, reducing the electrode 
area involved in the reaction [40,41]. The significant occurrence of oxygen evolution side reactions led to a decrease in current efficiency. As shown in Figure 1b, the ICE did not increase with the increase in current density when the current density increased from 50 to $60 \mathrm{~A} / \mathrm{m}^{2}$.
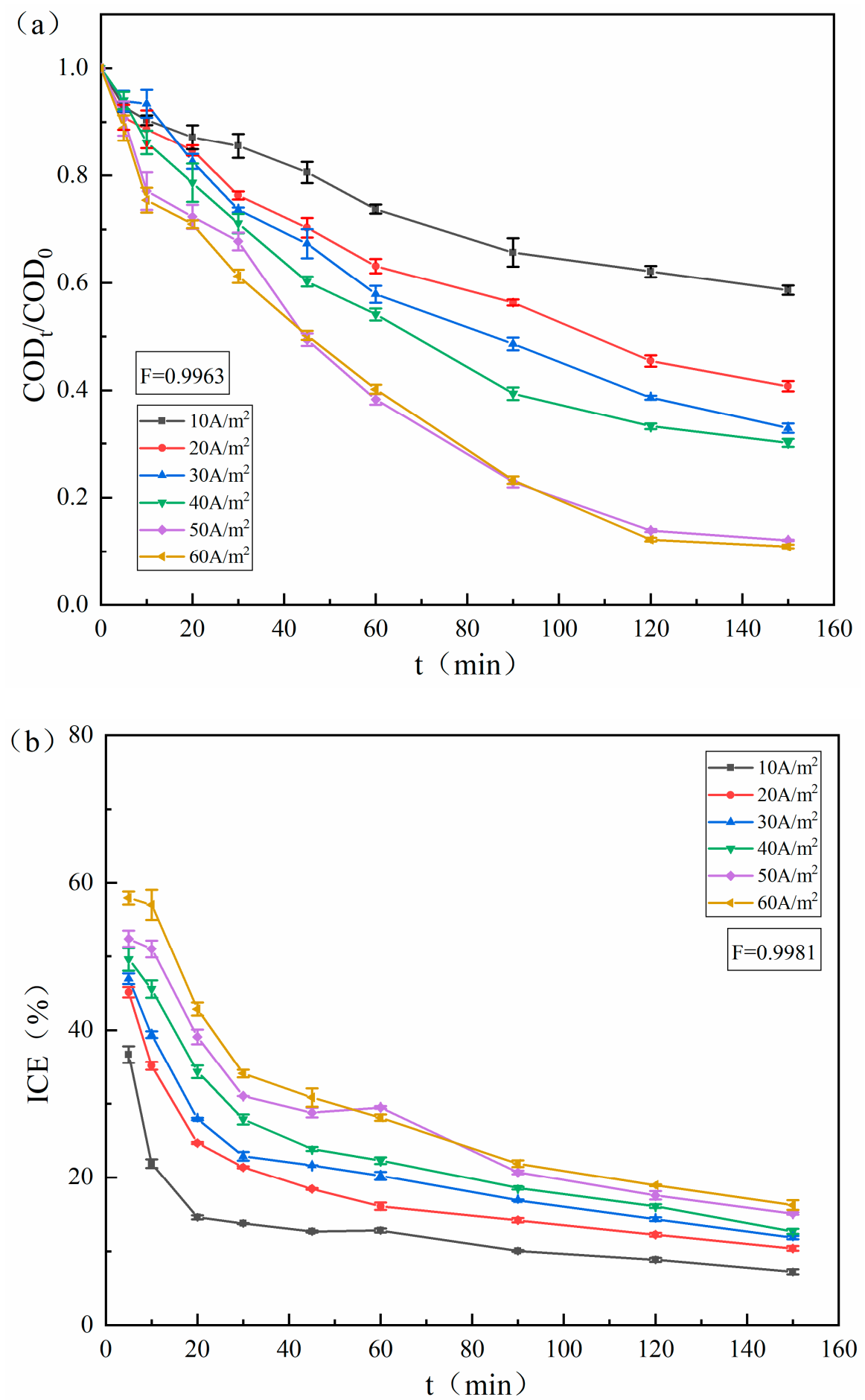

Figure 1. Cont. 

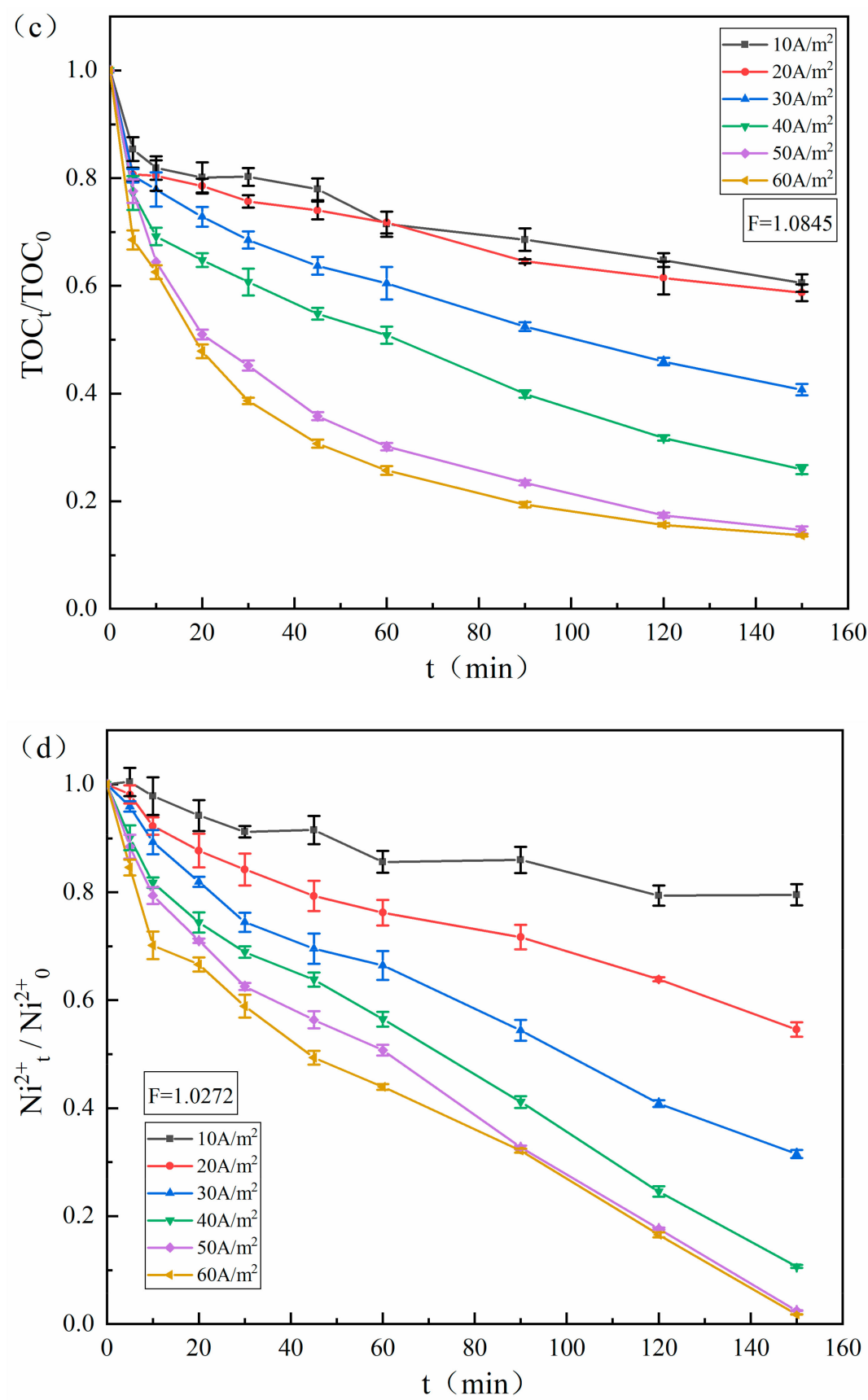

Figure 1. Evolution of $\mathrm{COD}_{\mathrm{Cr}}(\mathbf{a}), \operatorname{ICE}(\mathbf{b}), \mathrm{TOC}(\mathbf{c})$, and $\mathrm{Ni}^{2+}(\mathbf{d})$ as a function of time at different current densities. Electrolysis conditions: electroplating sludge leaching solution $(180 \mathrm{~mL})$, temperature $25^{\circ} \mathrm{C}$ and $\mathrm{pH} 3$.

The removal of TOC showed a similar pattern to $\mathrm{COD}_{\mathrm{Cr}}$. The removal rate of TOC increased with the increase in current density; when the current density was $50 \mathrm{~A} / \mathrm{m}^{2}$, the increase was no longer obvious, reaching more than $85 \%$, as shown in Figure $1 \mathrm{c}$. The high removal rate of TOC indicated that the generated $\cdot \mathrm{OH}$ was highly oxidizable and could be oxidized without any selection, which in turn led to a better mineralization of organics. However, the removal rates of $\mathrm{COD}_{\mathrm{Cr}}$ and TOC could reach $95.17 \%$ and $91.89 \%$ when Luu applied electrochemical oxidation to treat waste leachate. Compared with Luu's study, the removal rate of organic matter in this method still needs to be improved, and the next step is to conduct further study on anode modification, etc. [42].

Under the action of $\cdot \mathrm{OH}$, the structure of EDTA-Ni was disrupted to release $\mathrm{Ni}^{2+}$, which created conditions for $\mathrm{Ni}^{2+}$ deposition in the cathode. With the increase in current 
density and energization time, the $\mathrm{Ni}^{2+}$ removal rate increased continuously. As shown in Figure $1 \mathrm{~d}$, when the current density was $60 \mathrm{~A} / \mathrm{m}^{2}$, the removal rate of $\mathrm{Ni}^{2+}$ was larger than that of $50 \mathrm{~A} / \mathrm{m}^{2}$ for $60 \mathrm{~min}$, but the final removal rate was basically the same, mainly because the total amount of $\mathrm{Ni}^{2+}$ in wastewater was fixed. According to Faraday's first law, $m=M I t / z F$, when the current density is larger, the $\mathrm{Ni}$ in the cathode deposition inevitably increases, hence, the $\mathrm{Ni}^{2+}$ removal rate can be increased by increasing the current density in the early stage. As the concentration of $\mathrm{Ni}^{2+}$ in water decreases with electrolysis, the $\mathrm{Ni}$ can be deposited in the cathode, so the final removal rate is basically the same. When the concentration of $\mathrm{Ni}^{2+}$ in the electrolyte is small, the large current density leads to an increase in cathode hydrogen evolution side reactions, which competes with metal deposition [43].

\subsection{Effects of $\mathrm{pH}$ Value}

The $\mathrm{pH}$ value of the solutions affects the electrochemical process in two ways. First, it affects the oxygen evolution potential of the anode, and second, it affects the deposition and recovery efficiency of the cathode metal. At low $\mathrm{pH}$ value, the oxygen evolution reaction does not easily occur, but the increase in the cathode hydrogen evolution reaction affects the metal recovery rate at the cathode. High $\mathrm{pH}$ value affects the current efficiency and may exceed the metal solubility product, which may lead to precipitation and reduce the recovery rate. To better investigate the removal effect, the effect of different $\mathrm{pH}$ values $(2,3$, $4,5,6)$ on the treatment effect was investigated at a current density of $50 \mathrm{~A} / \mathrm{m}^{2}$.

Figure 2a,b shows the effect of $\mathrm{pH}$ on $\mathrm{COD}_{\mathrm{Cr}}$ and TOC, and it is easy to conclude that a lower $\mathrm{pH}$ value is beneficial to improving the oxidation effect of the electrochemical anode. During the degradation of the anode, $\cdot \mathrm{OH}$ oxidation of organics and oxygen evolution were two competing reactions. Under normal conditions, the higher the oxygen evolution potential of the anode under acidic conditions, the harder it is for the oxygen evolution reaction caused by the electrolysis of solvent water to occur, and the more $\cdot \mathrm{OH}$ is generated. The increase in the oxygen evolution reaction at a higher $\mathrm{pH}$ value led to a decrease in current efficiency, which was reflected by the decrease in the removal rate for $\mathrm{COD}_{\mathrm{Cr}}$ and TOC after the increase in $\mathrm{pH}$. At the same time, the adsorption and reaction activity of organics on the electrode surface were also affected by $\mathrm{pH}$ value; specifically, $\mathrm{pH}$ value affected redox potential and electrode surface charge. The rapid decrease in TOC at $\mathrm{pH}=2$ indicates that the acidic solution accelerated the removal of organic pollutants and mainly afforded easily degradable products [44-46].

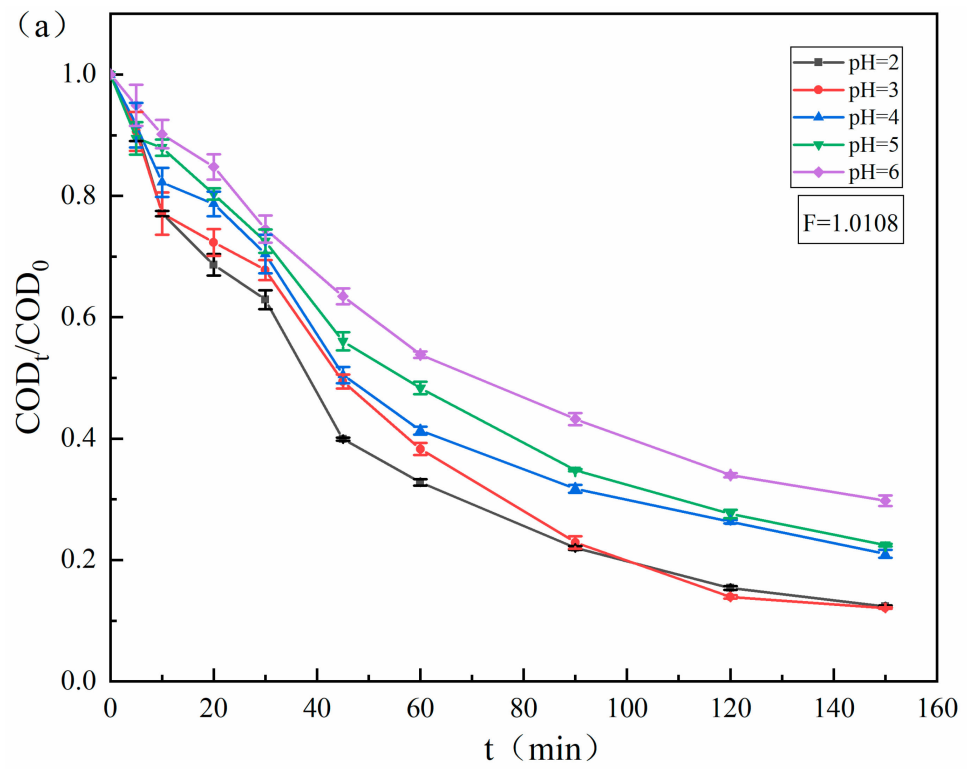

Figure 2. Cont. 

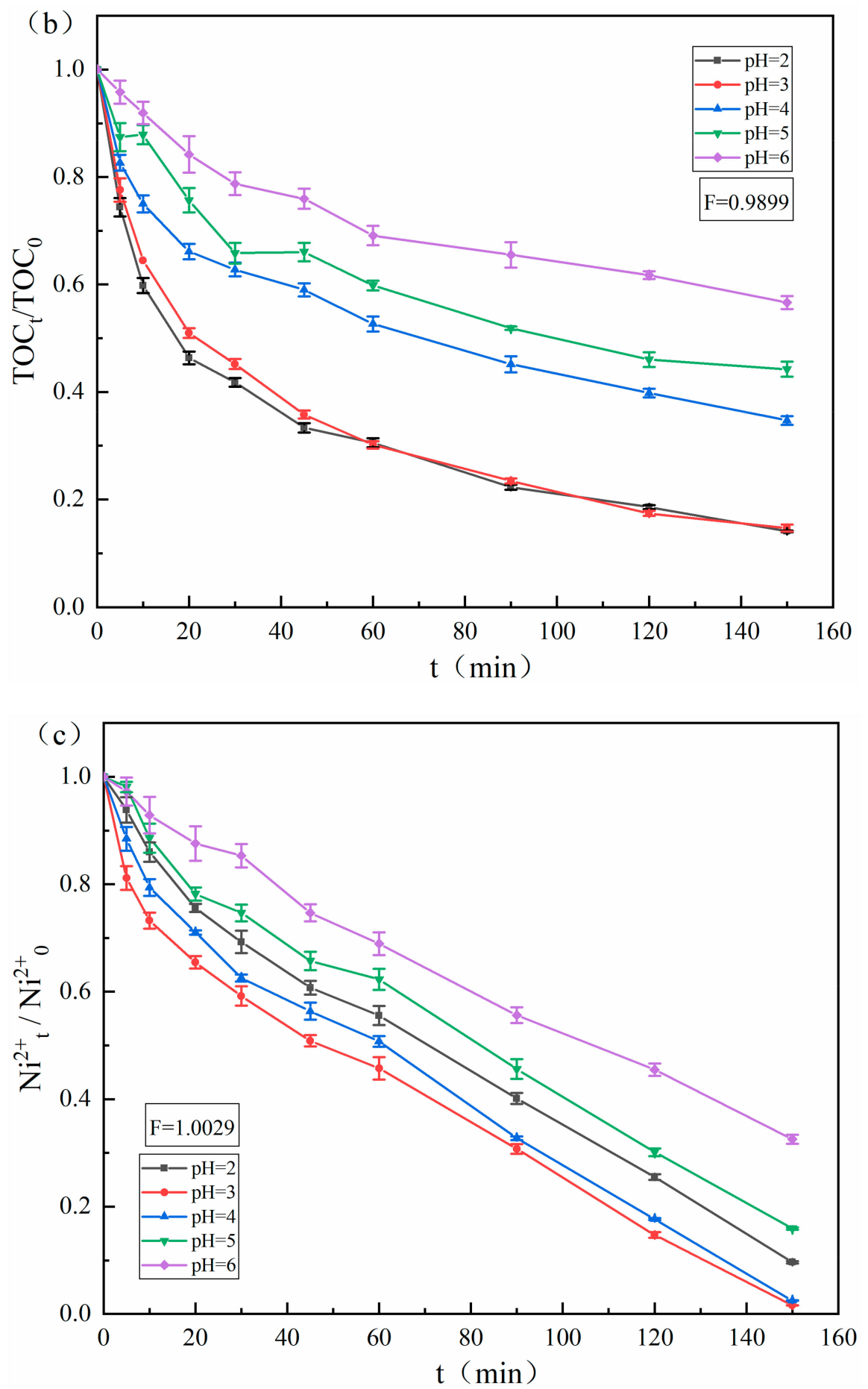

Figure 2. Cont. 


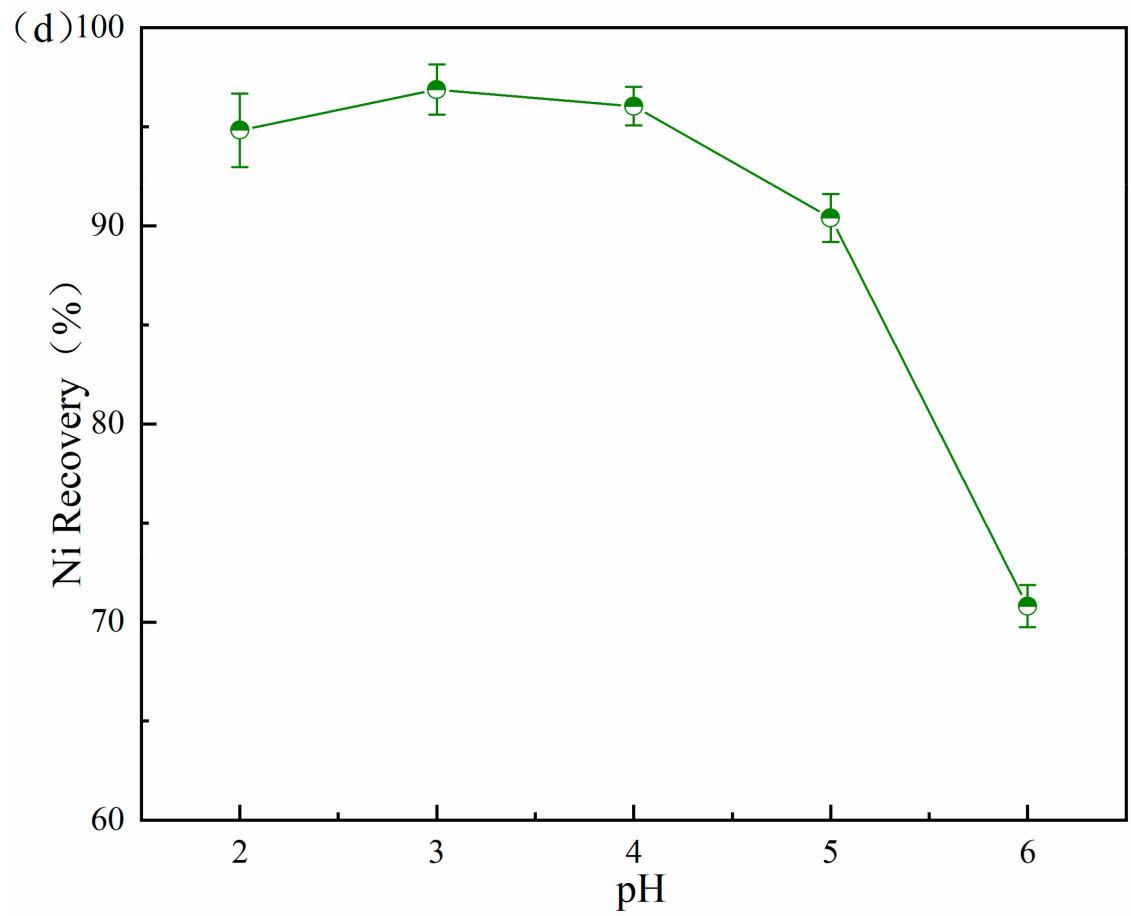

Figure 2. Evolution of $\mathrm{COD}_{\mathrm{Cr}}(\mathbf{a}), \mathrm{TOC}(\mathbf{b})$, and $\mathrm{Ni}^{2+}(\mathbf{c})$ as a function of time at different initial $\mathrm{pH}$. (d) The relationship between the $\mathrm{Ni}^{2+}$ recovery rate and $\mathrm{pH}$. Electrolysis conditions: electroplating sludge leaching solution $(180 \mathrm{~mL})$, temperature $25^{\circ} \mathrm{C}$, and current density $50 \mathrm{~A} / \mathrm{m}^{2}$.

The effect of $\mathrm{pH}$ value on cathode deposition was completely different, as higher or lower $\mathrm{pH}$ was not conducive to metal deposition or recovery (Figure 2c). At lower $\mathrm{pH}$ conditions, the proportion of cathode hydrogen evolution side reactions increased significantly, and various bubbles were clearly observed on the electrode surface and escaped from the electrode surface that competed with the metal deposition reaction in the cathode and affected the metal removal and recovery. At higher $\mathrm{pH}$ values, the cathode zone was alkalinized, and the metal recovery was reduced. As shown in Figure 2d, higher $\mathrm{pH}$ reduced the recovery by more than $20 \%$ [43]. Under the optimal conditions, the metal recovery of this method was $96.88 \%$. However, Yu et al. used chlorine with thermal regulation and directional phase conversion for the recovery of metals from electroplating sludge; the recovery rate was $97 \%$, which was comparable to the metal recovery of the present method [47].

\subsection{Effects of Chloride and Sulfate}

Due to the different production processes, electroplating sludge contains some chloride or sulfide in the production process, which will produce active chlorine or active sulfide in the electrochemical oxidation process. As the concentrations of sulfate and chloride in the leaching solution used in this study were below $0.01 \mathrm{M}$, the effect of the presence of chloride and sulfate on the electrochemical treatment was investigated by adding $0.1 \mathrm{M}$, $0.2 \mathrm{M} \mathrm{NaCl}$ and $\mathrm{Na}_{2} \mathrm{SO}_{4}$ to the solution. The current density was $50 \mathrm{~A} / \mathrm{m}^{2}$, with $\mathrm{pH}=3$. The results are shown in Figure 3.

Figure $3 a, b$ shows that the effects of chloride and sulfate on the removal of organics were reversed, and sulfate could increase the removal rate of organics, while chloride could weaken the removal of organics. This was mainly due to the difference in the oxidation capacity of the electrochemical anode to produce active chlorine and sulfate radicals $\left(\cdot \mathrm{SO}_{4}{ }^{2-}\right)$ [48]. The standard electrode potential of $\cdot \mathrm{SO}_{4}{ }^{2-}\left(E_{0}=2.7 \sim 2.8 \mathrm{eV}\right)$ was close to that of $\cdot \mathrm{OH}$ and had almost the same oxidation capacity. It was shown that the presence of $\cdot \mathrm{SO}_{4}{ }^{2-}$ was longer than that of $\cdot \mathrm{OH}$, which prolonged the reaction time with organics, and $\cdot \mathrm{SO}_{4}{ }^{2-}$ had a higher sustained oxidation capacity and therefore a higher 
degree of mineralization than that of $\cdot \mathrm{OH}$. At the same time, the sulfate radical had a wider oxidation range than $\cdot \mathrm{OH}$ and oxidized organics that could not be oxidized by hydroxyl radicals. Hence, after adding sulfate, the anode produced both $\cdot \mathrm{OH}$ and $\cdot \mathrm{SO}_{4}{ }^{2-}$, forming a cross synergistic oxidation, and the oxidation capacity of radicals was enhanced. The increase in the removal rate for $\mathrm{COD}_{\mathrm{Cr}}$ was higher than the increase in the removal rate for $\mathrm{COD}_{\mathrm{Cr}}$, which indicated that the mineralization ability of $\cdot \mathrm{SO}_{4}{ }^{2-}$ was stronger $[49,50]$. The active chlorine $\left(E_{\mathrm{HClO}}=1.49\right)$ was significantly less oxidizing than $-\mathrm{OH}$, and the active chlorine produced in the anode competed with $\cdot \mathrm{OH}$ and affected the removal effect [51,52]. Notably, the presence of chloride and sulfate did not particularly affect the removal of organics, and the main removal effect relied on $\cdot \mathrm{OH}$.

The addition of chloride and sulfate did not significantly promote the removal of $\mathrm{Ni}^{2+}$. Although the addition of $\mathrm{NaCl}$ or $\mathrm{Na}_{2} \mathrm{SO}_{4}$ is usually used to increase electrical conductivity, the addition of sodium salts reduced the solution resistance but hardly affected the charge transfer coefficient and did not change the reaction mechanism of Ni deposition. As shown in Figure $3 c$, after adding sodium salt, the removal rate of $\mathrm{Ni}^{2+}$ only slightly increased.

\subsection{Effect of Leachate Dilution}

Figure 4 shows the effect of the leachate after dilution on treatment effect. The removal rates of $\mathrm{COD}_{\mathrm{Cr}}, \mathrm{TOC}$, and $\mathrm{Ni}^{2+}$ showed a decreasing trend with the increase in dilution, and the removal rate of $\mathrm{Ni}^{2+}$ decreased most significantly. When the volume ratio of leachate to deionized water was reduced from 100:0 to 25:75, the removal rates of $\mathrm{COD}_{\mathrm{Cr}}$, TOC, and $\mathrm{Ni}^{2+}$ decreased by $7.98 \%, 6.77 \%$, and $83.81 \%$, respectively. This was because the conductivity of the diluted solution decreased and the electrochemical process slowed down, which led to a decrease in the quantity of reactive oxygen species produced by the anode and a weakening of oxidation capacity. The concentration of organic matter decreased after dilution, and the chance of collision between organic molecules with electrodes or electrochemically generated reactive oxygen species near the electrode surface decreased, resulting in a decrease in removal rates for $\mathrm{COD}_{\mathrm{Cr}}$ and TOC. When the concentration of metal ions in solution was small, the charge transfer in the solution during electrolysis slowed down, resulting in a slower cathodic electrodeposition reaction process that directly affected the degradation efficiency of $\mathrm{Ni}^{2+}$, which was consistent with the law of mass action of the reaction.

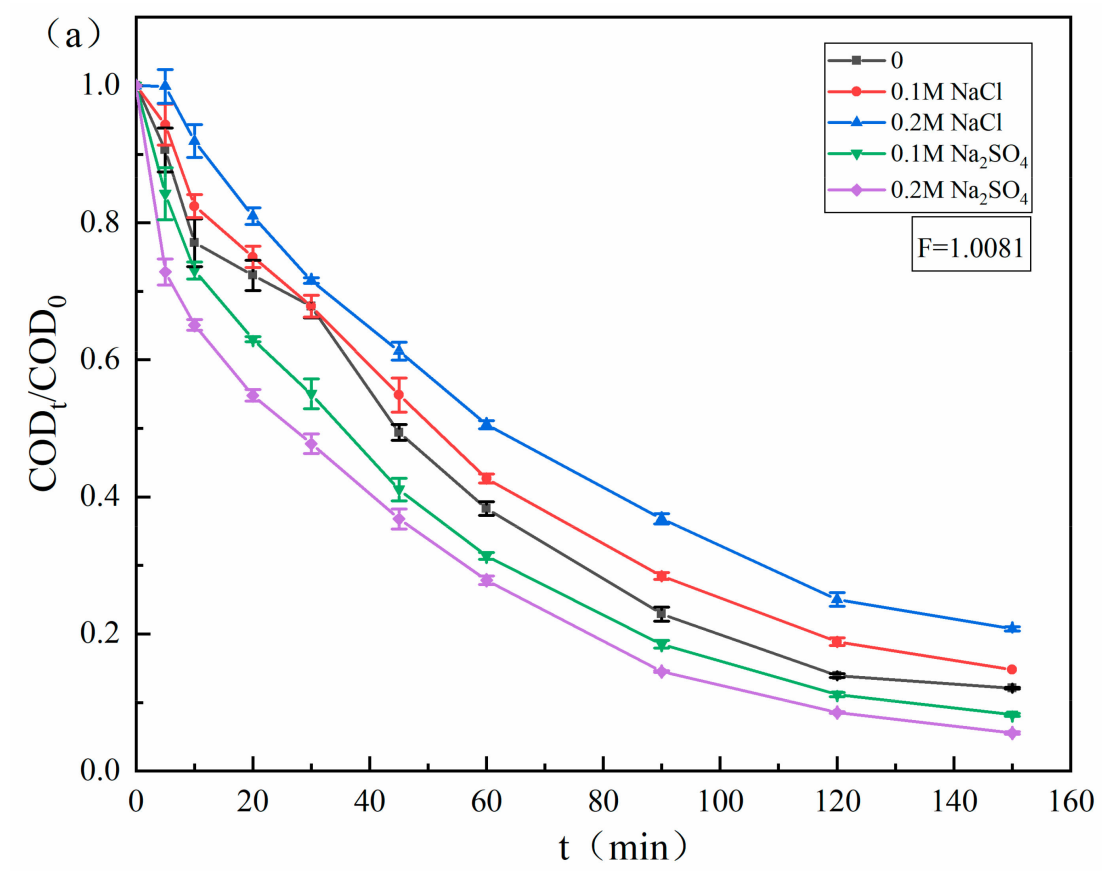

Figure 3. Cont. 

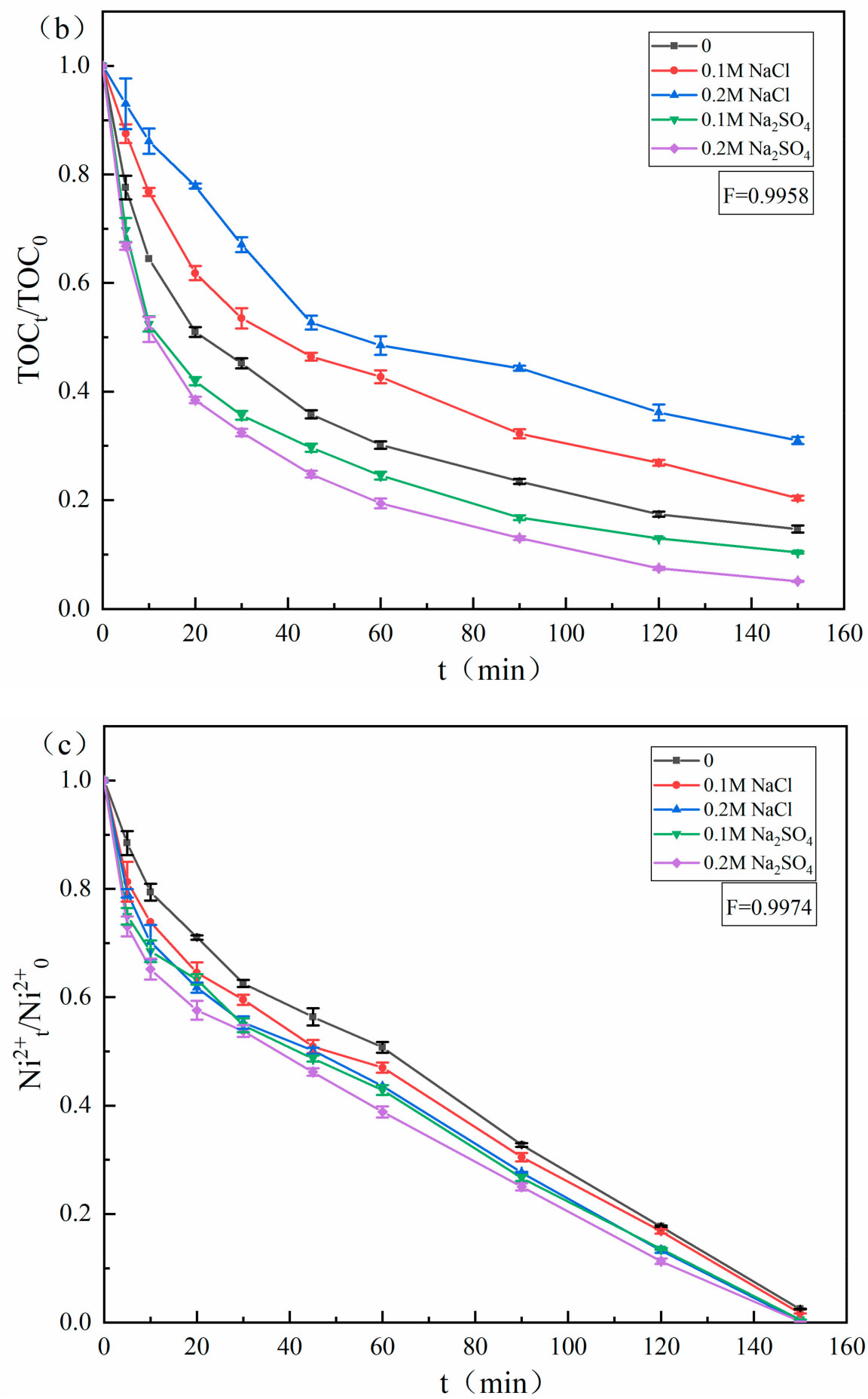

Figure 3. Evolution of $\mathrm{COD}_{\mathrm{Cr}}(\mathbf{a})$, $\mathrm{TOC}(\mathbf{b})$, and $\mathrm{Ni}^{2+}(\mathbf{c})$ as a function of time in different supporting media. Electrolysis conditions: electroplating sludge leaching solution $(180 \mathrm{~mL})$, current density $50 \mathrm{~A} / \mathrm{m}^{2}$, temperature $25^{\circ} \mathrm{C}$, and $\mathrm{pH} 3$. 


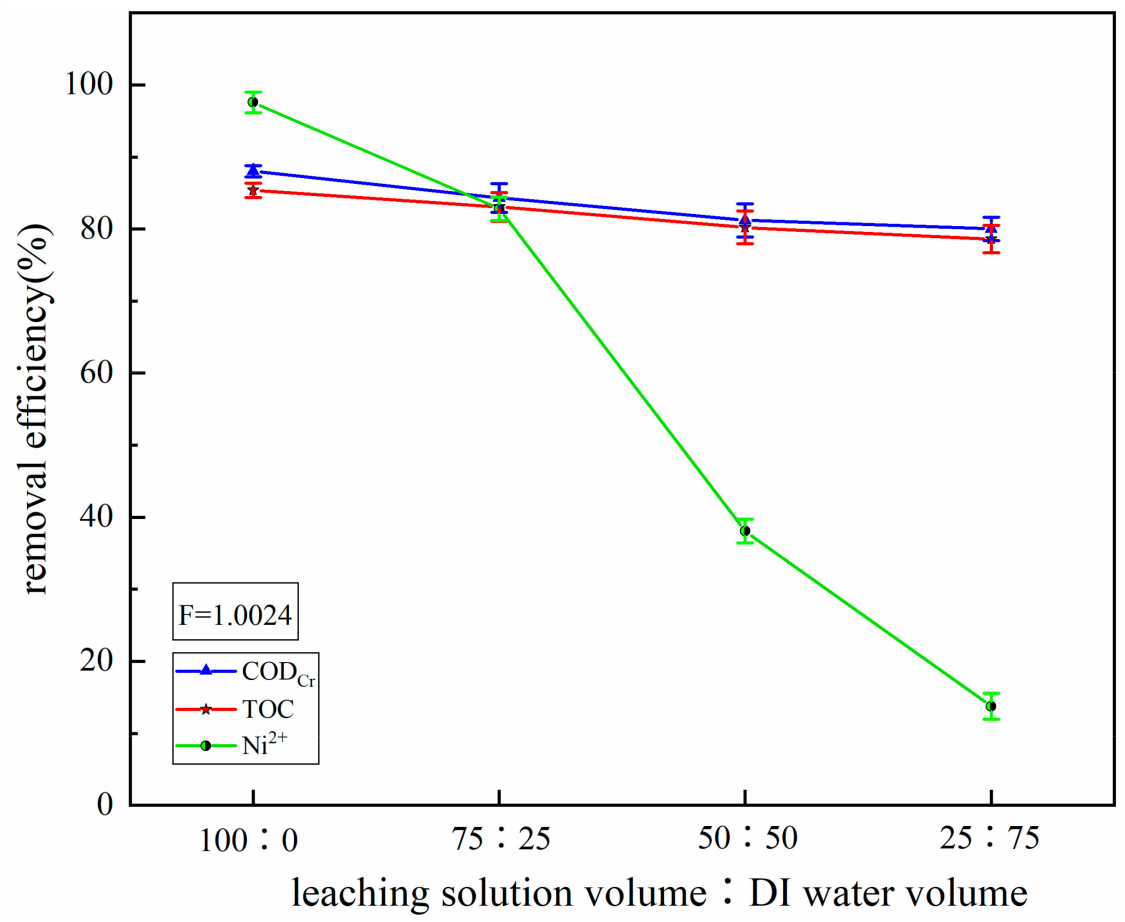

Figure 4. Relationship between the removal efficiency of $\mathrm{COD}_{\mathrm{Cr}}, \mathrm{TOC}$, and $\mathrm{Ni}^{2+}$ and dilution ratio. Electrolysis conditions: solution $180 \mathrm{~mL}$, current density $50 \mathrm{~A} / \mathrm{m}^{2}$, temperature $25^{\circ} \mathrm{C}$, and $\mathrm{pH} 3$.

\subsection{Inhibition of the Production of Organochloride By-Products}

Harmful organic chlorinated by-products, most commonly trihalomethanes (THMs), are produced after electrochemical treatment in some chlorine-containing systems. In this study, the primary amine group may have appeared in the degradation process of EDTA, which is a precursor of organochlorinated by-products. In order to investigate the inhibitory ability of the selected $\mathrm{SnO}_{2} / \mathrm{Ti}$ electrode for organic chlorinated by-products, $0.1 \mathrm{M} \mathrm{NaCl}$ was added to the electrolysis, and then the content of trihalomethanes (THMs) was measured after 150 min of electrolysis. The results are shown in Table 2. The experimental results showed that all the THMs were $\mathrm{CHCl}_{3}$, which would produce some harmful by-products in chlorine-containing systems; however, according to the literature, the quantity of by-products produced was lower than that of the other anode, and the non-active electrode had a better effect of inhibiting the production of by-products $[53,54]$.

Table 2. The number of THMs formed during the electrochemical oxidation under the optimal conditions $\left(50 \mathrm{~A} / \mathrm{m}^{2}, \mathrm{pH}=3,25^{\circ} \mathrm{C}\right.$, and supporting electrolyte of $0.1 \mathrm{M} \mathrm{NaCl}$ ) after $150 \mathrm{~min}$.

\begin{tabular}{ccc}
\hline Parameter & Unit & Value \\
\hline $\mathrm{CHCl}_{3}$ & $\mu \mathrm{g} / \mathrm{L}$ & 128 \\
$\mathrm{CHCl}_{2} \mathrm{Br}$ & $\mu \mathrm{g} / \mathrm{L}$ & 0 \\
$\mathrm{CHClBr}_{2}$ & $\mu \mathrm{g} / \mathrm{L}$ & 0 \\
$\mathrm{CHBr}_{3}$ & $\mu \mathrm{g} / \mathrm{L}$ & 0 \\
\hline
\end{tabular}

\section{Conclusions}

From the above results, it can be seen that the electrochemical redox designed in this study was an effective method for the treatment of electroplating sludge. Optimizing the design of electrochemical system parameters could further improve the prospects of its industrial application. Electrochemistry was used to achieve an effective, environmentally friendly disposal of electroplating sludge. Under optimal treatment conditions (current density $=50 \mathrm{~A} / \mathrm{m}^{2}, \mathrm{pH}=3$ ), the removal rates for $\mathrm{COD}_{\mathrm{Cr}}, \mathrm{TOC}$, and $\mathrm{Ni}^{2+}$ reached $88.01 \%$, $85.38 \%$, and $97.57 \%$, and the metal recovery was $97.01 \%$ within $150 \mathrm{~min}$. Increasing 
the current density and decreasing the $\mathrm{pH}$ value promoted the treatment of $\mathrm{COD}_{\mathrm{Cr}}$ and TOC. The removal rate of heavy metal was directly proportional to the current density. Too high or too low $\mathrm{pH}$ values were not conducive to metal recovery. However, the optimal $\mathrm{pH}$ value for the treatment of metals could meet the requirements for the treatment of organics. The removal of organics mainly relied on hydroxyl radicals generated by the anode oxidation process, while active chlorine and active persulfate generated by chloride and sulfate had less effect on the removal of organics. Dilution of the leachate would be detrimental to electrochemical treatment. The detection of organochloride byproducts after electrolysis showed that the $\mathrm{SnO}_{2}$ / Ti electrode well inhibited the generation of organochloride by-products, which were mainly $\mathrm{CHCl}_{3}$. After electrochemical treatment, the metal complex in electroplating sludge was destroyed, and the concentration of organics decreased significantly. The metal content was significantly reduced, which eliminated the toxicity and hazards of the electroplating sludge and provided the conditions for the next step of the biological method. More importantly, heavy metal wastes need to be properly disposed of in various areas including arid/semi-arid areas. In the disposal process, significantly polluted areas should be designated to prevent potential risks and hazards, with emphasis on reducing or eliminating the toxicity of heavy metal wastes while giving priority to the recovery of valuable metals to help achieve sustainable development.

Author Contributions: N.W. and S.W. conceived the main idea of the paper. N.W. and X.Z. (Xue Zhang) designed and performed the experiment. Y.L., X.Z. (Xuemin Zhang) and X.S. revised the manuscript and shared numerous comments and suggestions to improve the study quality. All authors have read and agreed to the published version of the manuscript.

Funding: Supported by the Science and Technology Program of Gansu Province (No. 20JR2RA002).

Institutional Review Board Statement: Not applicable.

Informed Consent Statement: Not applicable.

Data Availability Statement: No new data were created or analyzed in this study. Data sharing is not applicable to this article.

Acknowledgments: We thank the reviewers for their useful comments and suggestions.

Conflicts of Interest: The authors declare no conflict of interest.

\section{References}

1. Ministry of Ecology and Environment State; Development \& Reform Commission (incl. former State Development Planning Commission); Ministry of Public Security; Ministry of Transport; National Health Commission. National Hazardous Waste List (Version 2021); Directory of National Hazardous Wastes: Beijing, China, 2020. Available online: http:/ /www.mee.gov.cn/xxgk201 8/xxgk/xxgk02/202011/t20201127_810202.html (accessed on 1 June 2021).

2. Hou, Z.; Liu, T.; Tahir, M.U.; Ahmad, S.; Shao, X.; Yang, C.; He, B.; Su, X. Facile conversion of nickel-containing electroplating sludge into nickel-based multilevel nano-material for high-performance pseudocapacitors. Appl. Surf. Sci. 2021, 538, 141978. [CrossRef]

3. Sun, J.; Zhou, W.; Zhang, L.; Cheng, H.; Wang, Y.; Tang, R.; Zhou, H. Bioleaching of copper-containing electroplating sludge. J. Environ. Manag. 2021, 285, 112133. [CrossRef]

4. Nikfar, S.; Parsa, A.; Bahaloo-Horeh, N.; Mousavi, S.M. Enhanced bioleaching of Cr and Ni from a chromium-rich electroplating sludge using the filtrated culture of Aspergillus niger. J. Clean. Prod. 2020, 264, 121622. [CrossRef]

5. Zoqi, M.J.; Ganjidoust, H.; Mokhtarani, N.; Ayati, B. Solidification optimisation of electroplating sludge. J. Environ. Eng. Sci. 2016, 11, 33-43. [CrossRef]

6. Samadder, S.; Prabhakar, R.; Khan, D.; Kishan, D.; Chauhan, M. Analysis of the contaminants released from municipal solid waste landfill site: A case study. Sci. Total Environ. 2017, 580, 593-601. [CrossRef] [PubMed]

7. Przydatek, G.; Kanownik, W. Impact of small municipal solid waste landfill on groundwater quality. Environ. Monit. Assess 2019, 191, 169. [CrossRef] [PubMed]

8. Emami, S.; Negahdar, A.; Zarei, M. Investigating the influence of the leachate from the municipal solid waste on the mechanical and environmental properties of soil around the landfill (case study: The municipal landfill located in Ardabil-Iran). Arab. J. Sci. Eng. 2019, 44, 8417-8428. [CrossRef] 
9. Indelicato, S.; Orecchio, S.; Avellone, G.; Bellomo, S.; Ceraulo, L.; Di Leonardo, R.; Di Stefano, V.; Favara, R.; Candela, E.G.; La Pica, L.; et al. Effect of solid waste landfill organic pollutants on groundwater in three areas of Sicily (Italy) characterized by different vulnerability. Environ. Sci. Pollut. Res. 2017, 24, 16869-16882. [CrossRef] [PubMed]

10. Chabuk, A.; Al-Ansari, N.; Hussain, H.M.; Laue, J.; Hazim, A.; Knutsson, S.; Pusch, R. Landfill sites selection using MCDM and comparing method of change detection for Babylon Governorate, Iraq. Environ. Sci. Pollut. Res. 2019, 26, 35325-35339. [CrossRef]

11. Blight, G.E.; Fourie, A.B. Experimental landfill caps for semi-arid and arid climates. Waste Manag. Res. 2005, 23, 113-125. [CrossRef]

12. Al-Yaqout, A.F.; Hamoda, M.F. Evaluation of landfill leachate in arid climate-A case study. Environ. Int. 2003, 29, 593-600. [CrossRef]

13. Anwar, F.; Yaqout, A. Assessment and analysis of industrial liquid waste and sludge disposal at unlined landfill sites in arid climate. Waste Manag. 2003, 23, 817-824.

14. Basahi, J.M.; Masoud, M.H.Z.; Rajmohan, N. Effect of flash flood on trace metal pollution in the groundwater-Wadi Baysh Basin, western Saudi Arabia. J. Afr. Earth Sci. 2018, 147, 338-351. [CrossRef]

15. Fan, S.; Wang, X.; Lei, J.; Ran, Q.; Ren, Y.; Zhou, J. Spatial distribution and source identification of heavy metals in a typical Pb/Zn smelter in an arid area of northwest China. Hum. Ecol. Risk Assess. 2019, 25, 1661-1687. [CrossRef]

16. Ghosh, P.; Thakur, I.S.; Kaushik, A. Bioassays for toxicological risk assessment of landfill leachate: A review. Ecotoxicol. Environ. Saf. 2017, 141, 259-270. [CrossRef]

17. Al-Yaqout, A.; Hamoda, M.F. Long-term Temporal Variations in Characteristics of Leachates from a Closed Landfill in an Arid Region. Water Air Soil Pollut. 2020, 231, 319. [CrossRef]

18. Vargas-Machuca, B.D.; Zanetta-Colombo, N.; De Pol-Holz, R.; Latorre, C. Variations in local heavy metal concentrations over the last 16,000 years in the central Atacama Desert $\left(22^{\circ} \mathrm{S}\right)$ measured in rodent middens. Sci. Total Environ. 2021, 775, 145849. [CrossRef]

19. Maskooni, E.K.; Naseri-Rad, M.; Berndtsson, R.; Nakagawa, K. Use of heavy metal content and modified water quality index to assess groundwater quality in a semiarid area. Water 2020, 12, 1115. [CrossRef]

20. Ma, W. Investigation and Management of Industrial Hazardous Waste in Gansu Province. Master's Thesis, Lanzhou University, Lanzhou, China, January 2018.

21. Ye, S.S.; Chen, Y.X.; Yao, X.L.; Zhang, J. Simultaneous removal of organic pollutants and heavy metals in wastewater by photoelectrocatalysis: A review. Chemosphere 2020, 6, 128503. [CrossRef] [PubMed]

22. Martínez-Huitle, C.A.; Panizza, M. Electrochemical oxidation of organic pollutants for wastewater treatment. Curr. Opin. Electrochem. 2018, 11, 62-71. [CrossRef]

23. Kothari, M.S.; Shah, K.A. Electrochemical oxidation for decolorization of Rhodamine-B dye using mixed metal oxide electrode: Modeling and optimization. Water Sci. Technol. 2020, 81, 720-731. [CrossRef]

24. Carretero, D.S.; Huang, C.P.; Tzeng, J.H.; Huang, C.-P. The recovery of sulfuric acid from spent piranha solution over a dimensionally stable anode (DSA) Ti-RuO 2 electrode. J. Hazard. Mater. 2021, 406, 124658. [CrossRef] [PubMed]

25. Gonzaga, I.M.D.; Dória, A.R.; Vasconcelos, V.M.; Souza, F.M.; dos Santos, M.C.; Hammer, P.; Rodrigo, M.A.; Eguiluz, K.I.B.; Salazar-Banda, G.R. Microwave synthesis of $\mathrm{Ti} /\left(\mathrm{RuO}_{2}\right)_{0.5}\left(\mathrm{IrO}_{2}\right)_{0.5}$ anodes: Improved electrochemical properties and stability. $J$. Electroanal. Chem. 2020, 874, 114460. [CrossRef]

26. Santos, J.E.L.; Gómez, A.M.; Moura, D.C.; Cerro-López, M.; Quiroz, M.A.; Martinez-Huitle, C.A. Removal of herbicide 1-chloro2,4-dinitrobenzene (DNCB) from aqueous solutions by electrochemical oxidation using boron-doped diamond (BDD) and $\mathrm{PbO} 2$ electrodes. J. Hazard. Mater. 2021, 402, 123850. [CrossRef] [PubMed]

27. Chen, M.; Pan, S.; Zhang, C.; Wang, C.; Zhang, W.; Chen, Z.; Zhao, X.; Zhao, Y. Electrochemical oxidation of reverse osmosis concentrates using enhanced $\mathrm{TiO}_{2}-\mathrm{NTA} / \mathrm{SnO}_{2}-\mathrm{Sb}$ anodes with/without $\mathrm{PbO}_{2}$ layer. Chem. Eng. J. 2020, 399, 125756. [CrossRef]

28. Zhang, J.; Wei, X.; Miao, J.; Zhang, R.; Zhang, J.; Zhou, M.; Lu, W. Enhanced performance of an Al-doped SnO 2 anode for the electrocatalytic oxidation of organic pollutants in water. Mater. Today Commun. 2020, 24, 101164. [CrossRef]

29. Garcia-Segura, S.; Ocon, J.D.; Chong, M.N. Electrochemical oxidation remediation of real wastewater effluents-A review. Process Saf. Environ. Prot. 2018, 113, 48-67. [CrossRef]

30. Panizza, M.; Cerisola, G. Direct and mediated anodic oxidation of organic pollutants. Chem. Rev. 2009, 109, 6541-6569. [CrossRef]

31. Bobadilla, M.C.; González, O.V.P.; Lorza, R.L.; Somovilla Gómez, F. Effecting partial elimination of isocyanuric acid from swimming pool water systems. Water 2019, 11, 712. [CrossRef]

32. Krasner, S.W.; Mitch, W.A.; McCurry, D.L.; Hanigan, D.; Westerhoff, P. Formation, precursors, control, and occurrence of nitrosamines in drinking water: A review. Water Res. 2013, 47, 4433-4450. [CrossRef]

33. Ding, S.; Chu, W.; Bond, T.; Cao, Z.; Xu, B.; Gao, N. Contribution of amide-based coagulant polyacrylamide as precursors of haloacetamides and other disinfection by-products. Chem. Eng. J. 2018, 350, 356-363. [CrossRef]

34. Radjenovic, J.; Sedlak, D.L. Challenges and oppor. for electrochemical processes as next-generation technologies for the treatment of contaminated water. Environ. Sci. Technol. 2015, 49, 11292-11302. [CrossRef]

35. State Administration for Market Regulation; Standardization Administration. Treatment and Disposal for Electroplating SludgeClassification (GB/T 38066-2019); Standards Press of China: Beijing, China, 2019.

36. Chai, L.Y.; You, X.Y.; Shu, Y.D.; Yang, J.; Wang, Y.Y.; Zhao, N. Electrochemical degradation of organic wastewater containing EDTA with three-dimensional electrode reactor. J. Cent. South Univ. 2010, 41, 1240-1245. 
37. Zhao, B.; Zhu, W.K.; Mu, T.; Hu, Z.; Duan, T. Electrochemical oxidation of EDTA in nuclear wastewater using platinum supported on activated carbon fibers. Int. J. Environ. Res. Public Health 2017, 14, 819. [CrossRef]

38. Apollo, S.; Onyango, M.S.; Ochieng, A. An integrated anaerobic digestion and UV photocatalytic treatment of distillery wastewater. J. Hazard. Mater. 2013, 261, 435-442. [CrossRef] [PubMed]

39. Fukushima, M.; Tatsumi, K.; Nagao, S. Degradation characteristics of humic Acid during photo-fenton processes. Environ. Sci. Technol. 2001, 35, 3683-3690. [CrossRef] [PubMed]

40. Vargas, R.; Díaz, S.; Viele, L.; Núñez, O.; Borrás, C.; Mostany, J.; Scharifker, B.R. Electrochemical oxidation of dichlorvos on $\mathrm{SnO}_{2}-\mathrm{Sb}_{2} \mathrm{O}_{5}$ electrodes. Appl. Catal. Appl. Catal. B Environ. 2014, 144, 107-111.

41. Wei, J.Z.; Feng, Y.J.; Sun, X.; Liu, J.; Zhu, L. Effectiveness and pathways of electrochemical degradation of pretilachlor herbicides. J. Hazard. Mater. 2011, 189, 84-91. [CrossRef]

42. Luu, T.L. Post treatment of ICEAS-biologically landfill leachate using electrochemical oxidation with $\mathrm{Ti} / \mathrm{BDD}$ and $\mathrm{Ti} / \mathrm{RuO} 2$ anodes. Environ. Technol. Innov. 2020, 20, 101099. [CrossRef]

43. Ya, V.; Martin, N.; Chou, Y.-H.; Chen, S.-S.; Choo, K.-H.; Naddeo, V.; Le, N.C.; Li, C.-W. Efficient Cu removal from CuEDTA complex-containing wastewater using electrochemically controlled sacrificial iron anode. Chemosphere 2021, 264, 128573. [CrossRef]

44. Hu, X.; Dong, H.; Zhang, Y.; Fang, B.; Jiang, W. Mechanism of N,N-dimethylformamide electrochemical oxidation using a $\mathrm{Ti} / \mathrm{RuO}_{2}-\mathrm{IrO}_{2}$ electrode. RSC Adv. 2021, 11, 7205-7213. [CrossRef]

45. Wu, J.; Zhu, K.; Xu, H.; Yan, W. Electrochemical oxidation of rhodamine B by $\mathrm{PbO}_{2} / \mathrm{Sb}-\mathrm{SnO}_{2} / \mathrm{TiO}_{2}$ nanotube arrays electrode. Chin. J. Catal. 2019, 40, 917-927. [CrossRef]

46. Saadi, S.; Moteshaker, P.M.; Rokni, S.E.; Ahmadidoust, G.; Farnoodian, N.; Yousefi, A. The electrochemical degradation of the metronidazole (MNZ) antibiotic using electrochemical oxidation on a stainless steel 316 coated with beta lead oxide (SS316/ $\beta$ $\mathrm{PbO}_{2}$ ) anode. Int. J. Chem. React. Eng. 2020, 18, 20190026. [CrossRef]

47. Yu, Y.; Huang, Q.; Zhou, J.; Wu, Z.; Deng, H.; Liu, X.; Lin, Z. One-step extraction of high-purity CuCl2·2H2O from coppercontaining electroplating sludge based on the directional phase conversion. J. Hazard. Mater. 2021, 413, 125469. [CrossRef]

48. Wang, J.L.; Wang, S.Z. Reactive species in advanced oxidation processes: Formation, identification and reaction mechanism. Chem. Eng. J. 2020, 401, 126158. [CrossRef]

49. Lan, Y.; Coetsier, C.; Causserand, C.; Serrano, K.G. On the role of salts for the treatment of wastewaters containing pharmaceuticals by electrochemical oxidation using a boron doped diamond anode. Electrochim. Acta 2017, 231, 309-318. [CrossRef]

50. Chanikya, P.; Nidheesh, P.V.; Babu, D.S.; Gopinath, A.; Kumar, M.S. Treatment of dyeing wastewater by combined sulfate radical based electrochemical advanced oxidation and electrocoagulation processes. Sep. Purif. Technol. 2021, 254, 117570. [CrossRef]

51. Garcia-Segura, S.; Keller, J.; Brillas, E.; Radjenovic, J. Removal of organic contaminants from secondary effluent by anodic oxidation with a boron-doped diamond anode as tertiary treatment. J. Hazard. Mater. 2015, 283, 551-557. [CrossRef] [PubMed]

52. Zhang, L.; Xu, L.; He, J.; Zhang, J. Preparation of Ti/ $\mathrm{SnO}_{2}-\mathrm{Sb}$ electrodes modified by carbon nanotube for anodic oxidation of dye wastewater and combination with nanofiltration. Electrochim. Acta 2014, 117, 192-201. [CrossRef]

53. Anglada, A.; Ortiz, D.; Urtiaga, A.M.; Ortiz, I. Electrochemical oxidation of landfill leachates at pilot scale: Evaluation of energy needs. Water Sci. Technol. 2010, 61, 2211-2217. [CrossRef]

54. Katsoni, A.; Mantzavinos, D.; Diamadopoulos, E. Sequential treatment of diluted olive pomace leachate by digestion in a pilot scale UASB reactor and BDD electrochemical oxidation. Water Res. 2014, 57, 75-86. [CrossRef] [PubMed] 